\title{
Kablosuz Algılayıcı Ağlarında Trafik Kontrollü Gezgin Yönlendirme Yöntemi
}

\author{
Sercan YALÇIN*, Ebubekir ERDEM \\ Fırat Üniversitesi, Bilgisayar Mühendisliği Bölümü, Elazığ, Türkiye \\ (ORCID: 0000-0003-1420-2490) (ORCID: 0000-0001-7093-7016)
}

\begin{abstract}
$\ddot{\mathbf{O} z}$
Kablosuz algılayıcı ağlarında (KAA), verimli veri iletimi için algılayıcı düğümleri ve gezgin alıcı (toplayıcı) düğümleri arasında sağlam bir yönlendirme protokolünün tasarlanması çok önemlidir. KAA'da, gezgin alıcı düğümlerin rastgele hareketliliği, patlak trafik durumlarında ağdaki paket gecikmesini artırır. Bu nedenle, bu çalışmada, heterojen KAA'lara dayalı bir patlak trafik kontrollü yönlendirme yöntemi aktarılmıştır. Önerilen yöntemde, algılayıcı düğümleri ağ alanına dağıtıldığında, ağ alanı her birinde belirli sayıda küme bulunan iki küme grubuna bölünmektedir. Algılayıcı ağında, her küme grubuna ait birer gezgin alıcı düğüm görev yapar. Bu gezgin alıcı düğümler, önerilen patlak trafik tabanlı bir gezginlik metodu ile seçilen gezgin yollar sayesinde, küme başlarına varır varmaz tek-atlamalı tutumla tüm verileri toplar. Bu şekilde, enerji yükü ağ arasında paylaştırılarak dengeli enerji tüketimi sağlanır. Önerilen gezginlik modelinde, patlak veri sezildiği anda, gezgin alıcı düğüm yörüngesini patlak verinin olduğu küme başına doğru güncelleyerek ağdaki verileri toplar. Önerilen yöntemi doğrulamak için Ubuntu 14.04 LTS platformunda kurulu NS-2 benzetim yazılımında performans analizleri yapılmıştır. Benzetim sonuçları, önerilen yöntemin güncel çalışmalara kıyasla, ağ ömrünü artırdığını ve ortalama enerji tüketimini azalttığını göstermektedir.
\end{abstract}

Anahtar kelimeler: Kablosuz Algılayıcı Ağları, Kümeleme ve Yönlendirme Modeli, Gezgin Alıcılı Düğümler, Enerji Verimliliği.

\section{Traffic Controlled Mobile Routing Method in Wireless Sensor Networks}

\begin{abstract}
In wireless sensor networks (WSNs), it is essential to design a robust routing protocol between sensor nodes and mobile sinks for data transmission efficiently. In WSN, random mobility of mobile sinks increases packet latency in the network in burst traffic situations. Therefore, in this study, a burst traffic controlled routing method based on heterogeneous WSNs is introduced. In the proposed method, when the sensor nodes are distributed in the network area, the network area is divided into two cluster groups, each with a certain number of clusters. In the sensor network, a mobile sink of each cluster group acts. These mobile sinks collect all data in a single-hop attitude as soon as they arrive at the cluster, thanks to the mobile paths selected with a proposed burst traffic-based mobility method. In this way, the energy load is shared among the network, making it balanced. In the proposed mobility model, once burst data is detected, the mobile sink collects data on the network by updating its trajectory towards the beginning of the cluster where the burst data is located. Performance analyzes have been performed on the NS2 simulation software installed on Ubuntu 14.04 LTS platform to verify the proposed method. The simulation results show that the proposed method increases the network lifetime and reduces the average energy consumption compared to recent studies.
\end{abstract}

Keywords: Wireless Sensor Networks, Clustering and Routing Model, Mobile Sinks, Energy Efficiency.

\section{Giriș}

Kablosuz Algılayıcı Ağları (KAA), gerçek ortamlarda hizmet vermek için birbirleriyle iletişim kuran dağıtılmış ve ucuz maliyetli birçok algılayıcı düğümlerinden oluşur [1,2]. KAA uygulamaları olarak akıllı şebeke, sağlık hizmetleri, akıllı köprüler, hassas tarım, endüstriyel uygulamalar, kentsel arazi takibi, savaş alanının hedef yeri, fizyolojik veri toplama ve akıllı ulaşım sistemi [3] gibi birçok

*Sorumlu yazar: svancin@firat.edu.tr

Geliş Tarihi: 15.02.2021, Kabul Tarihi: 16.04.2021 
uygulamalar sayılabilir [4]. KAA'da, dağılmış algılayıcı düğümlerinin her birinin birincil işlevi, ortamda algıladıkları verileri diğer algılayıcılara iletmek veya alıcı düğümüne teslim etmektir [5]. Bir alıcı dügümü, KAA'yı mevcut bir iletişim yapısına bağlama yeteneğine sahip sabit bir düğüm veya hareketli (gezgin) bir dügü̈mdür [6]. Geleneksel KAA'larda, algılayıcı düğümleri ve merkezi bir alıcı arasındaki veri toplama, tek atlama veya çoklu atlama iletişimine dayanır. Bununla birlikte, veri toplama yöntemleri enerji ve yük dengeleme kısıtlamaları ile karşı karşıya kalmaktadır [7,8]. Statik alıcı durumunda, alıcılara yakın olan düğümler, çok atlamalı yolların kesişmesiyle alıcıya doğru daha fazla veri trafiğinin oluşması nedeniyle var olan enerjiyi daha hızlı tüketir [9]. Bu sorun sıcak nokta (hot spot, hole) problemi olarak adlandırılır. Buna karşılık, gezgin alıcı (GA) belirli yörüngeler üzerindeki hareket nedeniyle KAA'da yük dengelemesini ve optimum enerji tüketimini sağlar [10].

Algılayıcı dügümlerinin gezginliği kontrollü ve kontrolsüz gezginlik olmak üzere iki tür olabilir. Kontrol edilemeyen gezginlikte, algılayıcı dügümleri ă̆ alanında rastgele hareket etmekte serbesttir ancak kontrollü gezginlikte, ağ ömrü boyunca önceden tanımlanmış yolu izlemeleri gerekir. Kontrollü gezginlik ayrıca kendi arasında iki türe ayrılır. Birincisi, GA düğ̈mün ağ ömrü boyunca (sabit geçici olarak kalma, fixed sojourn) konumlarını izleyerek uyarlanabilir gezgin rotanın keşfedebilmesidir. $\mathrm{Bu}$ kontrollü gezginlik esnek olmayan gezginlik türü olarak adlandırılır. İkincisi ise ağın ömrünü en üst düzeye çıkarmak için her turdaki gezgin algılayıcı düğümleri için sabit geçici yerleri seçilir. Bu kontrollü gezginlik uyarlanabilir, sağlam ve esnek bir gezginlik türü olarak bilinir [11-13]. Bu çalışmada, adaptif ve kontrollü bir gezginlik tekniği önerilmiştir.

KAA'lar içerdikleri algılayıcı dügümm özelliklerine göre homojen ve heterojen ağlar olmak üzere ayrilırlar. Homojen düğümlü ağlar birbirine eşit fiziksel ve yazılımsal özellikteki düğümleri içerir, heterojen yapılı ağlarda ise tersi durum söz konusudur. A $\breve{g}$ içerisindeki düğüm çeşitliliğin olması ve enerjinin farklı miktarda ve sürede tüketilmesi ağın enerji ve yük dengesinin sağlanması açısından heterojen KAA'lar oluşturulması diğerine nispeten avantajlıdır.

Alıcı gezginliği KAA'ya önemli avantajlar sağlasa da, yönlendirme protokolleri tarafından veri iletişimi ve yönetim sorunları ile karşı karşıya kalmaktadır [14]. Bu nedenle, KAA'lardaki gezginlik ile başa çıkmak için yönlendirme protokollerini uyarlamak gerekir. Yönlendirme yapısına bağlı olarak hiyerarşik, düz ve konum tabanlı yönlendirme protokolleri olmak üzere sinıflandırılır [15]. Diğer yönlendirme türleriyle karşılaştırıldığında, hiyerarşik tabanlı yönlendirme protokolleri enerji, ölçeklenebilirlik ve gezgin KAA'ların ömrünü uzatma açısından daha iyi performans sağlar [11]. Mevcut veri toplama yöntemlerinin çoğu, üst üste binmeyen kümeleri bir küme başı $(\mathrm{KB})$ ile üreten KAA'larda kümeleme yöntemi gibi hiyerarşik tabanlı yönlendirme mekanizmasını kullanır [16]. Buna rağmen, algılayıcı dügümleri ve alıcı dügümleri arasında verimli bir veri toplamanın modellenmesi, farklı gezginlik düzenleri üzerinde enerji verimli bir $\mathrm{KB}$ seçimi yaparak realistik heterojen KAA'lar tasarlamak kritik önem arz etmektedir.

Zhang ve Wan [17]'in önerdiği patlama trafiğine sahip GA'lar için dinamik yol planlama algoritması (Dynamic Path Planning for Mobile Sink with Burst Traffic, DPPMSBT), KAA'da yükü dengelemeyi ve trafik darboğazlarını önlemeyi amaçlamaktadır. Bu algoritma, ağın ızgara bölümlerini, öncül iz oluşturma, trafik yoğunluğu farkındalığı ve tahmini, kaynaklar işbirliği stratejisi ve dinamik yönlendirme düzenlemesini göz önüne almaktadır.

Naghibi ve Barati [18], algılayıcı ağını coğrafi bölge şeklinde ayarlaması için bir yöntem (Energy efficient geographic routing protocol based on mobile sink, EGRPM) önermiştir. Bu bölgelerdeki hücre olarak adlandırılan alanlarda bulunan dügümler ortamdaki verileri algılar ve bu verileri toplamak için iki GA dügüm kullanır. Düğümler ve GA dügüm arasındaki iletişim hücrede tek sekmeli iletişim hücreleri (SCCs) ve çok sekmeli iletişim hücreleri (Multi-CCs) olmak üzere iki sınıfta gerçekleşir. Bu iki sınıf içerisinde GA dügümler tüm verileri toplar ve ana merkeze iletir. Önerilen bu yöntemler sayesinde ağ ömrü ve paket teslim oranı önemli ölçüde artmasına ve enerji tüketimini azalmasına rağmen, trafik yoğunluğu ve paket çakışması gibi riskli senaryolar önerdikleri çalışmada hesaba katılmamışır.

Toor ve Jain [12], algılayıcı ağın ömrünü uzatmak için 3 seviyeli heterojen KAA'larda GA dügümler kullanılarak enerji farkındalı kümeleme tabanlı (Mobile energy aware cluster based multihop, MEACBM) bir yöntem sunmuşlardır. Bu yöntemle, KB'ler enerjisi en yüksek dügümlerden seçilir. KB'ler küme üyelerinden verileri toplar. Bundan sonra, ağ alanı sektörlere bölünür. Her sektöre ait bir GA dügüum bulunur. $\mathrm{Bu}$ alıcı düğümler Beklenti-Maksimizasyon (Expectation-Maximization, EM) algoritmas1 sayesinde KB'lerden verileri toplayarak baz istasyonuna (BS) teslim ederler. Öte yandan, 
önerilen şemada, kümelerdeki algılayıcı düğümlerinin ölçeklenebilirliği zayıftır ve GA düğümün hızı adaptif olarak tayin edilmemiştir. Bu yüzden ağdaki enerji dengesi yeterli şekilde sağlanamamıştır.

Yalçın ve Erdem [19], heterojen gezgin ağlar için bakteri etkileşimi temelli KB seçimi ve iletim sınırı menzilli bilişsel yönlendirme algoritması olarak yeni bir yaklaşımla iki algoritma önermiştir. Etkileşim farkındalı̆̆g değeri, enerji düğümü derecesi ve bitişik düğümlere olan uzaklığı parametrelerini esas alan açgözlü yaklaşımla daha güvenilir ve güçlü KB seçimi yapılmıştır.

Bu doğrultuda, bu çalışmada önerilen yöntemler ile enerji tasarruflu veri toplanmasını sağlamak için GA'larla patlama trafiği farkındalı̆̆ geliştirilmiştir. Önerilen gezginlik modelleri kullanılarak, heterojen KAA'larda enerji yük dengeleme ve ağ ömrünün artırılması gibi birçok sorunlara çözüm sunulmaktadır.

\section{Materyal ve Metot}

Önerilen yaklaşım, doğrudan veya komşu KB'ler yoluyla en yakın alıcı düğümlerine ulaşmak için en kısa yollarla ilgili bilgileri içerir ve KB'lerin yardımıyla rotayı dinamik olarak güncellemektedir. Şekil 1, bu çalışmanın yöntemleriyle beraber genel sürecini göstermektedir. Önerilen metodoloji standart trafik senaryolarında en kısa rotaları kullanır. Bu çalışmada 2 tane GA dügümm kullanılmakla birlikte, 1. alıcı düğüm 1. küme grubundan sorumlu, 2. alıcı düğüm 2. küme grubundan sorumlu tutulmaktadır. Patlak trafik ise benzetimde paket hızını ve miktarını artırarak oluşturulmaktadır. Patlama trafiği sırasında, önerilen yaklaşım birden fazla alıcı dügümünden verileri optimum rotalardan yük dengeleme hedefine toplar. Bu trafik hangi küme grubunun dâhilinde ise o gruba ait olan GA devreye girecektir. Bir anlamda, GA dügüm patlak trafik verileri toplaması için öncelik oluşturulur. Daha sonra diğer KB hedeflerine hızını artırarak hareket eder ve algılayıcı verilerini geri kaldığı yerden toplamaya devam eder. Bu şekilde, diğer alıcı düğümlerine alternatif en uygun yol seçerek, normal dügümmlerdeki enerji tükenmesini etkili bir şekilde önler. Bu nedenle, önerilen yöntem adaptif bir alıcı hareketliliğine dayalı veri toplama yoluyla ağda dengeli enerji tüketimi sağlar.

\section{1. Çalışmanın Enerji Modeli}

Bu çalışmada daha önceki çalışmamızda [19] önerilen enerji modeline benzer bir model benimsenmiştir. $\mathrm{Bu}$ enerji modelinde, toplam enerji tüketimi, veri iletimi ve alımı işlemi sırasında tüketilen enerji, veri algılama için ve kanalı dinleme için tüketilen enerji olmak üzere 4 kategoride ele alınmıştır. Yani, önceki çoğu çalışmalarda, algılama ve dinleme süreçlerinde enerji tüketim analizleri görmezden gelinmiştir. Çünkü bu süreçlerde algılayıcı düğümlerinin daha az enerji tükettiği iddia edilmiştir. Bu anlamda, veri algılama ve kanal dinleme için harcanan enerji maliyetleri de dikkate alınmıştır. Bu sayede daha gerçekçi enerji analizi yapıldığını söyleyebiliriz.

Veri iletimi ve alımı için tüketilen enerji modellerinin analizinde, iletim ve alım tüketimi $E_{T X / R X}$ için bir algılayıcı düğümünün enerji tüketimi denklem (1)'deki gibi ölçülür. Burada $l$, veri boyutudur, $E_{\text {elec }}$ vericiyi veya alıcıyı elektronik olarak çalıştırmak için algılayıcının bit başına enerji tüketimini gösterir, $e_{f s}$ ve $e_{a m p}$, sirasıyla boş ve çok yollar için radyo amplifikatörlerinin tiplerini gösterir. $E_{T X / R X}(l, d) l$ bitleri için veri gönderip alırken enerji tüketimini temsil eder.

$E_{T X / R X}(l, d)=\left\{\begin{array}{c}l E_{\text {elec }}+l e_{f s} d^{2}, d<d_{0} \\ l E_{\text {elec }}+l e_{\text {amp }} d^{4}, d \geq d_{0}\end{array}\right.$

Veri göndermek ve almak için tüketilen enerjinin birbiriyle aynı olduğunu varsayıyoruz. Referans mesafesi $d_{0}$ denklem (2)'de hesaplanır.

$d_{0}=\sqrt{\frac{e_{f s}}{e_{a m p}}}$

Kanal dinleme ve veri algılama için tüketilen enerji modelinde ise, bir $t$ dinleme zamanında, sabit enerji denklem (3)'teki gibi ifade edilebilir. 
$E_{c e}=A+L_{\text {cost }} . t$

Burada, $A$ sabit bir farkındalık maliyeti, $L_{\text {cost }}$ dinleme maliyetidir. Bununla birlikte, bir Zaman Bölmeli Çoklu Erişim (Time Division Multiple Access, TDMA)-döngüsü sırasında $N_{a w}$ farkındalık sayısını hesaplamak gereklidir. Dolayısıyla, $T$ periyodu ve $N$ algılayıcı dügümleri için bir periyottaki toplam dinleme maliyeti denklem (4)'te hesaplanmıştır.

$E_{\text {list }}=T N_{a w} N\left(E_{c e}\right)$

Algılama sürecinde enerji tüketiminin dinleme süreci ile aynı olduğu varsayılmaktadır. $\mathrm{Bu}$ anlamda, $E_{\text {sens }}$ algılama işleminin enerji tüketimi denklem (5)'teki gibi verilebilir.

$E_{\text {sens }}=E_{\text {list }}$ hesaplanır.

Bu nedenle, $r$ turunda dügüm $i$ için ilişkili olan toplam enerji tüketimi $E_{i}^{r}$ denklem (6)'ya göre

$E_{i}^{r}=E_{T X}(l, d) * n d_{i}+E_{R X}(l, d) *\left(n d_{i}-S_{i}\right)+2 E_{\text {list }}$

Burada $n d_{i}$, dügüum $i$ 'nin yük iletimini belirtir ve $n d_{j}$ dügüm $i$ 'nin ilişkili dügüümü olan dügüm $j$ 'nin yük iletimidir. $S_{i}$, düğüm $i$ tarafindan üretilen paketleri ifade eder. $n d_{i}$, denklem (7)'deki gibi hesaplanır. Burada $f_{i}$, düğüm $i$ 'nin KB olduğunda sahip olduğu küme üyesi dügüm sayısıdır.

$n d_{i}=\left\{\begin{array}{cc}\sum_{j \in f_{i}} n d_{j}+S_{i}, & \text { ĕger } f_{i} \neq \varnothing \\ S_{i}, & \text { yoksa }\end{array}\right.$

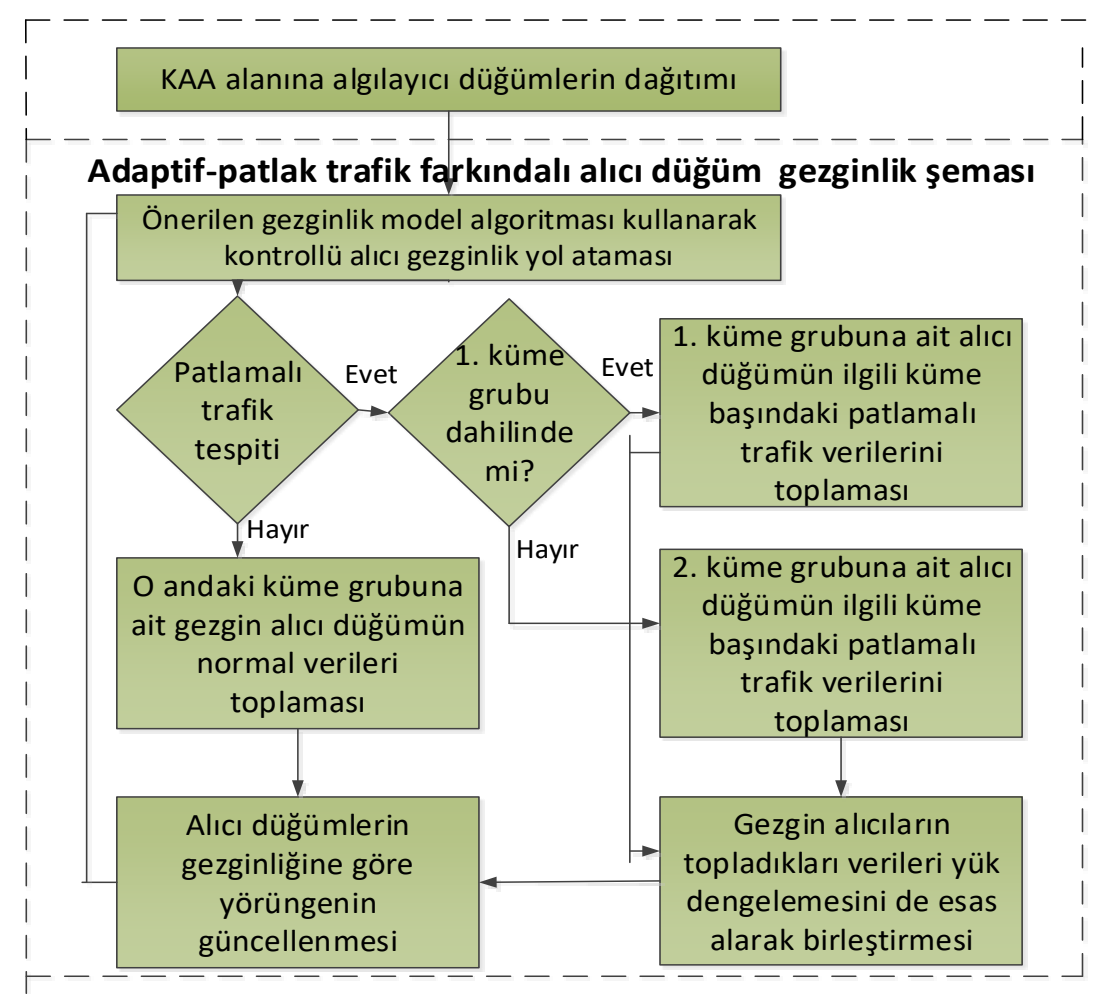

Şekil 1. Çalışmanın önerilen yöntemleriyle beraber genel süreci 


\section{2. Çalışmanın A $\breve{g}$ Modeli}

$\mathrm{Bu}$ çalışmadaki KAA senaryolarında, farklı boyutlarda ă̆ alanına farklı sayıda algılayıcı düğümü rastgele dağıtılır. Bir algılayıcı düğümünün bitişik düğümlerden uzaklığı alınan sinyal gücü göstergesi (RSSI) parametresine göre hesaplanabilir. Bu çalışmada, gezgin heterojen KAA oluşturulmuştur. Çalışmamızdaki KAA, sayıları toplam $N$ olan ve denklem (8)'deki gibi $N_{n r m}, N_{\text {adv }}$ ve $N_{\text {sup }}$ olarak temsil edilen normal, gelişmiş ve süper düğümler dâhil olmak üzere 3 seviyeli heterojen yapısına sahiptir.

Normal, gelişmiş ve süper düğümler enerji, veri işleme, iletim kapsamı, iletişim ve birçok özellik bakımından birbirinden farklı özelliklere sahiptir. Fakat bu çalışmada düğümlerin sadece enerji bakımından farklı olduğunu varsayıyoruz. Ağda, KB’ler genellikle normal düğümler yerine gelişmiş ve/veya süper düğümlerden seçilir. Ağ içerisinde enerji dengesi sağlandığında tüm düğümlerin enerjileri birbirine yakın değerde olabileceğinden dolayı KB'ler normal düğümlerden de seçilebilir. Seçilen KB'lerden veri toplayan GA düğümü sınırsız enerjiye sahip olduğu varsayılmaktadır. Algılayıcı ağındaki kalan düğümler normal düğüm özelliğine sahiptir.

$N=N_{n r m}+N_{a d v}+N_{\text {sup }}$

Gelişmiş ve süper düğümler, normal düğümlerden sırasıyla $\omega$ ve $\varphi$ kat fazla enerjiye sahiptir. Ağdaki normal, gelişmiş ve süper düğümlerin enerjileri sırasıyla $E_{n r m}, E_{a d v}$ ve $E_{\text {sup }}$ olmak üzere denklem (9)-(11) ile verilebilir.

$E_{n r m}=E_{0} x N_{n r m}$

$E_{a d v}=E_{0} x N_{a d v} x(1+\omega)$

$E_{\text {sup }}=E_{0} x N_{\text {sup }} x(1+\varphi)$

Burada $\omega$ ve $\varphi$, enerji katsayıları olduğu için fraksiyonel olarak 1 ile toplanmıştır. Buna göre ağın toplam enerjisi $E_{t}$ denklem (12)'deki gibi verilebilir. Burada $E_{t}$, farklı türdeki enerjiye sahip tüm dügümlerin enerjisi olduğundan dolayı, $E_{n r m}, E_{a d v}$ ve $E_{\text {sup }}$ enerjilerinin toplamından oluşur. Bu toplam enerji denklem (6)'daki enerji tüketimine göre zamanla harcanır ve tamamen biter.

$E_{t}=E_{n r m}+E_{a d v}+E_{\text {sup }}$

\section{3. Çalışmanın Patlak Trafik Modeli}

Bu çalışmada, patlak trafik, KB'lerin çevreden ve küme üyelerinden elde ettikleri aşırı şişmiş ve yoğun verilerin oluşturduğu trafik yükü olarak tanımlanır. Normal ve sağlıklı veriler belli bir dügümmde düğümün üstesinden gelemeyeceği kadar birikince algılayıcı düğümün çalışmasını bozabilir. Diğer yandan, bazı veriler algılayıcı dügümünde oluşan fiziksel veya yazılımsal arıza sonucu yeteneklerini yitirebilir. Bu zararlı durumlar, çalışmamızdaki trafik senaryolarının ilham kaynağıdır. Bu sebeple, önerilen algoritmada herhangi bir KB dügümünde patlak trafik olduğu tespit edilirse veya tahmin edilirse ki bu patlak trafik farkındalık fonksiyonuna göre belirlenir, veriler kaybolmasın ve algılayıcı dügü̈münün fonksiyonelliğini kaybetmesin diye ait olduğu KB'nin en yakını ve en yüksek enerjili olan bir başka dügümde yedeklenir. GA düğüm patlak trafik senaryolarında acilen bu verilerin olduğu yedeklenmiş düğüme hareket eder ki patlak trafik verilerini düzgün şekilde toplayabilsin. Bu sayede KB'nin sağlığı bu açıdan garanti altına alınmış olunur ve sağlıklı ve güvenilir verilerin özelliği bozulmadan yedeklenip kaybolma ve paket düşmesi riski azaltılır.

Literatürde, ağ trafiğini modellemek için ON/OFF trafik dağılım modeli önerilmiştir [20]. ON prosesi trafik akışının devam etttiğini, OFF prosesi ise trafiğin akışına ara verildiğini ve uyku durumda olduğunu gösterir. Bu modele göre, ilk önce her düğüm, $\lambda$ oranına sahip bir Poisson sürecini izleyen bir trafik üretir, daha sonra her düğüm bir trafiği izler. Paketlerin yalnızca işlem ON durumdayken üretildiği 
bir patlak (bursty) işlem tanımlanır. Önceki modellerin hiçbiri, ağır kuyruklu ve kendine benzeyen patlamış trafiği esas almamıştır.

Bu çalışmada, KAA'da küme üye dügümmleri tarafindan oluşturulan trafiği modellemek için NBURST trafik modeli önerilmiştir. Burada, ON ifadesi lojik " 1 " ile OFF ise lojik " 0 " ile ilişkilendirilmiş̧ir. Tampon taşması olasıllğ 1 (buffer overflow probability) gibi performans ölçümleri analitik olarak elde edilip farklı $B_{\text {dec }}$ patlama parametresi (burst parameter) altında KB'lerdeki patlak trafik olduğuna ve bu verilerin yedeklenmesi gerektiğine karar verilmektedir.

Çalışmamızda kullanılan N-Burst 1/0 modeli, ON / OFF modelinin bir türevidir. N-Burst hedefe (KB'ye) varış sürecinde, $\mathrm{N}$ bağımsız küme üyesinden gelen 1 / 0 türündeki veri trafik akışlarının KB'lerde birleştirilmesidir. " 1 " süresince her kaynak $\lambda B_{\text {dec }}$ hızında paketler üretir ve " 0 " süresi boyunca paket üretmez. Çok fazla ve hızlı veri paketi teorik olarak düşünüldügünde; $\lambda B_{d e c} \rightarrow \infty$ olursa bir veri bloğundaki tüm paketler aynı anda gelir ve trafik modeli bir yük (bulk) çıktısına dönüşür.

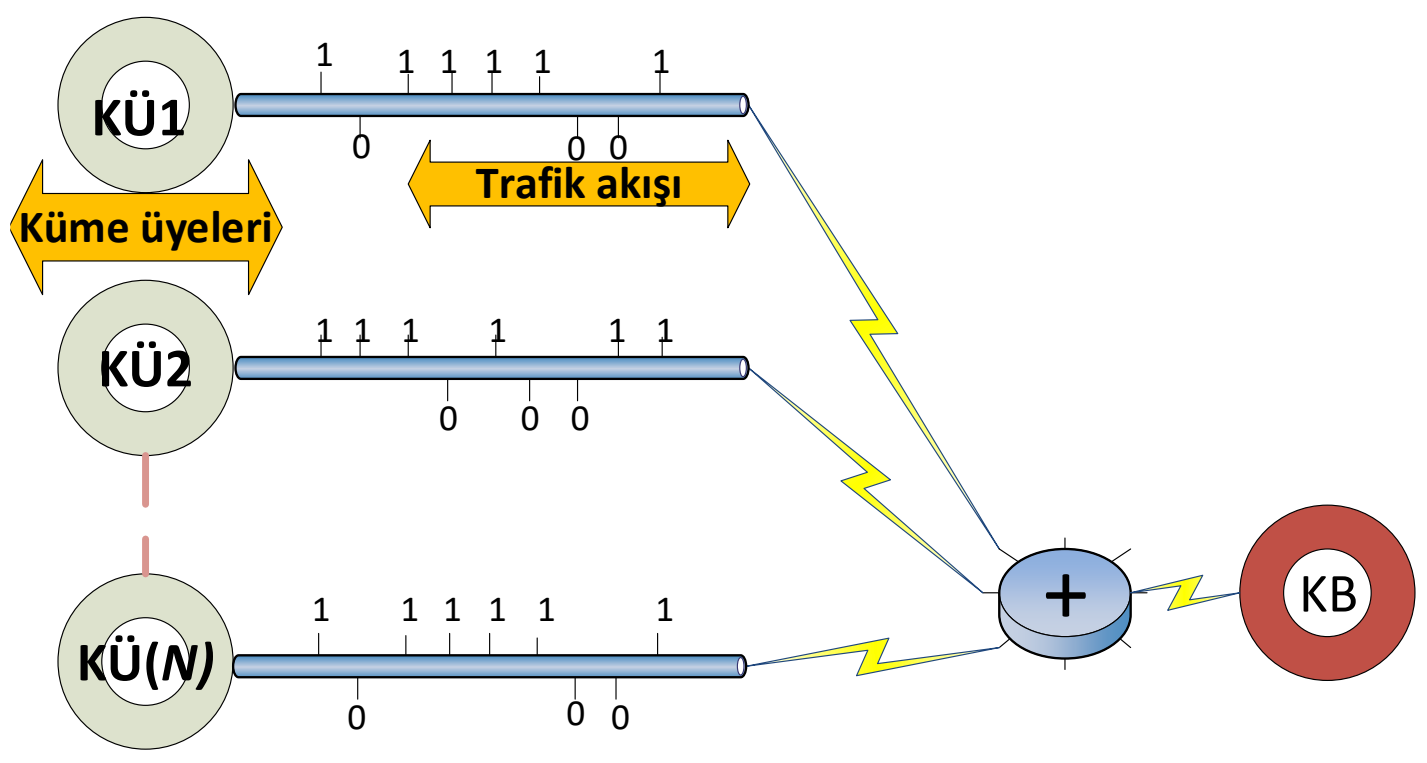

Şekil 2. Önerilen çalışmadaki N-Burst trafik modeli

Oluşturulan KAA modelinde, bir küme bir veya birden fazla algılayıcı küme üyesi düğümlerinden $(\mathrm{KÜ})$ oluşur. Bu dügümmler her biri 1-Burst trafik modeline göre veri üretir. Tüm küme üyeleri tarafindan oluşturulan verileri toplayan bir KB bulunur. Küme üyeleri, Şekil 2'de gösterildiği gibi doğrudan $\mathrm{KB}$ ile iletişim kurabilmektedir. Bu şekilde, N-Burst trafik modelini kullanarak tek düğümlü trafik modelini tanımlıyoruz. $k$ her düğüm için ortalama varış oranı (1 ve 0 için birlikte ortalama), $\partial$ düğümler tarafından oluşturulan toplam varış oranıdır (zaman birimi başına paket), burada $\partial=k K_{u}$ dir. $K_{u}$ bir kümedeki üye dügüm sayısıdır. Bu üye düğümler sadece bir KB'ye veri gönderir. $n_{\rho}$ ve $\partial_{\rho}$, sirasıyla, bir patlama sirasındaki ortalama paket sayıs1 ve tepe iletim hizıdır. $1=n_{\rho} / \partial_{\rho}$, bir patlama için ortalama $\mathrm{ON}$ süresidir. 0 , seri çekim arasındaki ortalama 0 (uyku süresi) süresidir. $v$, KB'nin ortalama paket servis hızıdır (zaman birimi başına paket). $\rho=\partial / v$, KB kullanım oranıdır.

Bütün bu açıklamalara dayanarak, patlaklık (burstiness) parametresi $B_{\text {dec }}$ denklem (13)'teki gibi tanımlanır. Burada $\rho=\partial / v$, KB kullanım oranı olduğundan, $B_{\text {dec }} 1$ ile çıkarılarak bulunmuştur.

$B_{d e c}=1-\frac{k}{\partial_{\rho}}$

N-küme düğümü KAA trafik ağı modelinde tüm olası dağılımlar için $B_{d e c}=0$ ve $B_{d e c}=1$ için sınırlayıcı durumlara bakarak patlak trafiğe karar verilir. Tampon taşma olasılıkları (buffer overflow probability), algılayıcı düğüm arızası gibi nedenlerle patlak trafiğe karar vermek için, $B_{d e c}$ 'in 1'e çok yakın olması gerekir. Paket hızı arttıkça kaynağın bir patlama iletme süresini kısalttığı için, $B_{d e c}=1$ 'de toplu varış limitine yükselir. Ayrıca, bu karar değeri $B_{d e c}$ 'nin monoton olarak artan bir fonksiyonudur. 
Denklem (14) ile her KB için patlak trafik bayrağını (PTB) (burst traffic flag, BTF) kullanarak patlak trafik olup olmadığına karar verilir.

Şekil 3’te KB'nin veri tutma oranına göre patlak trafik kararının verilmesini göstermektedir. KB'nin veri tutma oranı, bir KB'nin üzerindeki saklayabildiği paket sayısının ölçüsüdür.

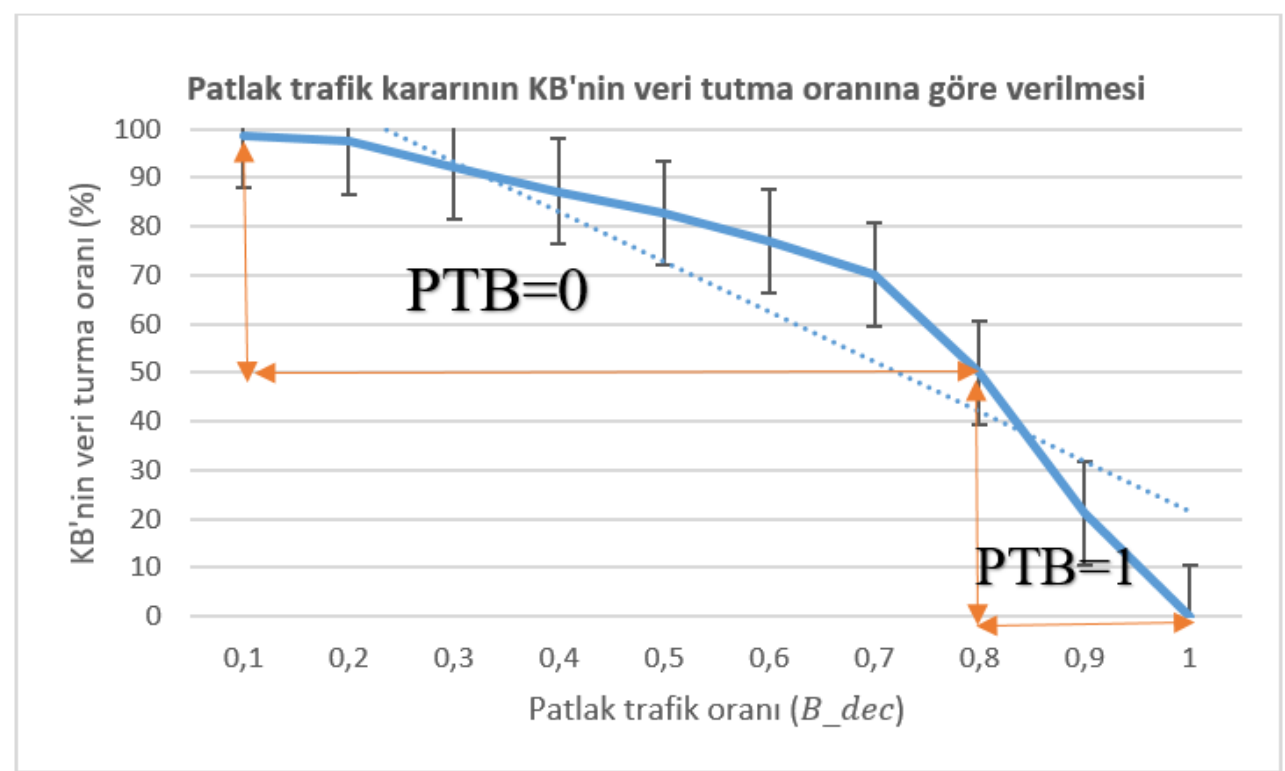

Şekil 3. Patlak trafik kararının KB’nin veri tutma oranına göre verilmesi

Şekil 4'te de görüldügü üzere patlak trafik oranı arttıkça KB'nin veri tutma oranı azalmaktadır. KB'lerin minimum yarı perfromans ile çalışabildiğini düşünerek $B_{\text {dec }}$ değeri 0.8 iken veri tutma oranı \%50'nin altına düşmektedir. Bu yüzden, $P T B$ değerini belirlerken $B_{d e c}$ sınır değeri 0.8 olarak belirlenmiştir. Eğer $B_{d e c}$ örneğin 0.8 'den büyükse $B T F=1$, değilse $P T B=0$ (normal trafik, smooth traffic) olarak patlak trafik kararı verilmiş olur.

$P T B=\left\{\begin{array}{rr}1, & \text { eğer } B_{d e c} \geq 0.8 \\ 0, & \text { diğer }\end{array}\right.$

\section{4. Önerilen Mobil Yönlendirme Yöntemi}

Önerilen yöntem, optimal rota seçimi ile birlikte 2 adet GA dügüm kullanmaktadır. Önerilen adaptif alıcı gezginlik modeli, optimum yol seçimi KB kapsama sınırına hareket yöntemi ve trafik farkındalı rotalamayı esas aldığı için kontrollü gezginlik model özelliği taşımaktadır.

Şekil 4 önerilen grup kümeli ve patlak trafik farkındalı heterojen KAA topolojisini göstermektedir. Şekil 4'te de görüldüğü üzere 2 farklı küme grubundan sorumlu 2 farklı GA, KB'lerden algılayıcı düğümlerin gönderdiği verileri toplamaktadır. A ̆ğ yapısı oluşurken GA düğümler tüm KB'lere kendilerine dâhil olması için "JoinRequest" istek mesajı gönderir. Algoritma 1'e göre bu kümeler alıc1 dügümlerden birini tercih etmek zorunda kalır. İlgili KB'ler "JoinAccept” cevap mesajı alıcı dügüme göndererek küme grubuna dâhil olmayı kabul ederler. Sonuç olarak 2 farklı küme grubu oluşacaktır. GA dügümler önerilen gezginlik modeline göre KB'lerin kapsama alanına girer girmez verileri toplamaktadır. Önerilen alıcı dügüm gezginlik modeli patlak trafiğin de farkındadır. Yani aşırı yoğun ve şişmiş veriler acil olarak toplanması gerekir. Aksi takdirde bu veriler kaybolabilir. Örneğin, önerilen algoritmaya göre, 1. alıcı düğ̈̈m 1. KB'den sonra 2. KB'ye gitmesi gerekirken 8. KB'deki patlak trafik verilerini toplayabilmek için acil olarak 8. KB'nin yedeğini tutan 8 . KB'ye en yakın 8x KB'ye gitmek zorunda kalır. Patlak trafiğin olduğu dügüme giderken alıcı dügümün hızı artar. Bu sayede, veri toplama gecikmesi azaltılmış olur. 8x KB 8. KB'deki verilerin kaybolma ihtimaline karşıllk verileri tutan bir algılayıcı düğ̈̈mdür. Aslında, patlamalı trafik oluşacağını sezdiği an her KB'nin yedeğini tutan bir en yakın dügüm bulunur. Daha sonra GA düğüm sirasıyla 7, 2 ve 3. diğer KB'leri ziyaret ederek kaynak noktasına varır ve bir turunu tamamlanmış olur. 2. küme grubunda ise; algoritmaya göre, 2. alıcı dügüm 
sirasiyla 10, 6 ve 5. KB'leri ziyaret ettikten sonra 4. KB'ye gitmesi gerekirken 9. KB'deki patlak trafik verilerini toplayabilmek için acil olarak en yakın 9. KB'nin yedeğini tutan 9y KB'ye gitmek zorunda kalır. Daha sonra GA düğüm sırasıyla 4. diğer KB'yi ziyaret ederek en sonunda kaynak noktasına varır ve bir turunu tamamlanmış olur. Bu şekilde patlak trafik farkındalı yöntemle paket kaybı önemli ölçüde azalt1labilmektedir.

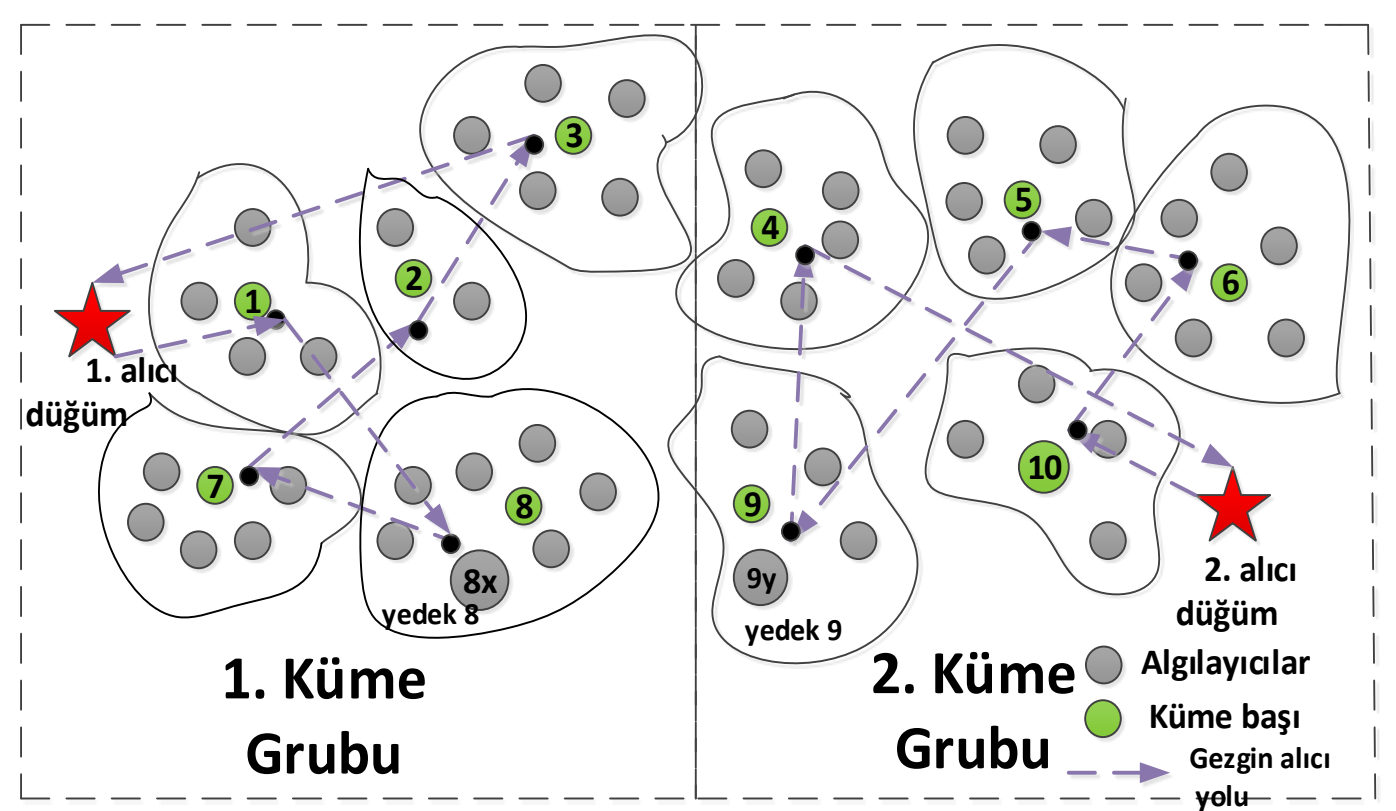

Şekil 4. Önerilen grup kümeli ve patlak trafik farkındalı heterojen KAA topolojisi

KB'ler seçildikten sonra $\left(K B^{r}\right)$, oluşturulan grafta bulunan çeşitli konumlardaki KB'ler önerilen Algoritma 1'deki APTsırala algoritmasına göre sıralanır. Başlangıçtaki graftaki algılayıcı düğüm sıralamalarına göre değil tanımlanan her KB'lerin konumlarını içeren yolların bulunduğu bir graftaki yol güzergâhlarının ağırlık nesnesine $(w)$ göre siralanır. Bu ağırlık nesnesi önerilen efektif ağırlık tabanlı bir fonksiyona göre oluşturulur. GA düğüm, minimum ağırlık nesnesine sahip güzergâhı tüm yol listesinden seçer ve bu yola göre hareket eder.

Daha sonra, adaptif bir GA yönlendirme problemi tanımlıyoruz.

Problem Tanımlama: Adaptif gezgin alıcı yönlendirme problemi

Bu aşamada, araç yönlendirme problemi [21] tabanlı bir problemi (VRP) tanımlıyoruz. Denklem (15)'te GA'lar tarafından gezilen kenarların uzunluklarını minimize etmek amaçlanır.

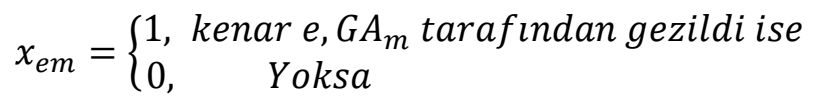

Burada, $x_{e m}$, toplamda $E$ kenar içerisinde $e$ kenarının $m$. GA tarafından gezilip gezilmediğini tanımlar. $\mathrm{Bu}$ çalışmada 2 adet GA var olduğu için $m=2$ 'dir. Kenar uzunluğu ise denklem (16)'da $d_{e}$ ile tanımlanmıştır. Dolasıyla tüm kenar uzunluklarının minimize edilmesi gerekir.

Minimize edilir $\sum_{\boldsymbol{e} \in E} d_{e} \sum_{m=1}^{2} x_{e m}$

Denklem (17) 'de $y_{i m} r$. tur için $i . \quad K B^{r}{ }_{i}$ dügümün GA tarafından gezilip gezilmediğini tanımlar. Dahası, $y_{i m}$ değeri $K B^{r}$ set içinde herhangi bir $i$ düğümü mutlaka $G A_{m}$ tarafından gezileceği için denklem (18)'deki gibi toplamı 1'dir.

$y_{i m}=\left\{\begin{array}{c}1, K B^{r}{ }_{i}, G A_{m} \text { tarafindan gezildi ise } \\ 0, Y \text { oksa }\end{array}\right.$
$\sum_{m=1}^{2} y_{i m}=1 \forall i \in K B^{r}$ set $\backslash\{0\}$ 
$x_{e m}$ ve $y_{i m}$ birbiriyle kenar düğüm ilişkisi çift yönlü olduğundan ötürü denklem (19) sağlanmalıdır.

$\sum_{e \in \gamma(i)} x_{e m}=2 y_{i m} \forall i \in K B^{r}$ set $m=1,2$

Burada $\gamma(i), i$. dügüm için kenar-dügüm bağlantısını ifade etmektedir. Ayrıca GA düğüm için $r$. tur için tüm $K B^{r}$ set içindeki dügümleri dolaşacağı ve diğer tur için başlangıç noktasına döneceği için kenarlar düğümlerden fazla olacağından ötürü $x_{e m} \geq 2 y_{j m}$ şartı denklem (20)'deki gibi sağlanmalıdır.

$\sum_{e \in \gamma(S)} x_{e m} \geq 2 y_{j m} \forall i K B^{r}$ set $\backslash\{0\}$,

$$
j \in S, m=1,2
$$

Bu probleme çözüm sunmak adına Problem Çözümü’nde denklem (22) ve (23) ile hesaplayabilmek için, Algoritma 1'i öneriyoruz.

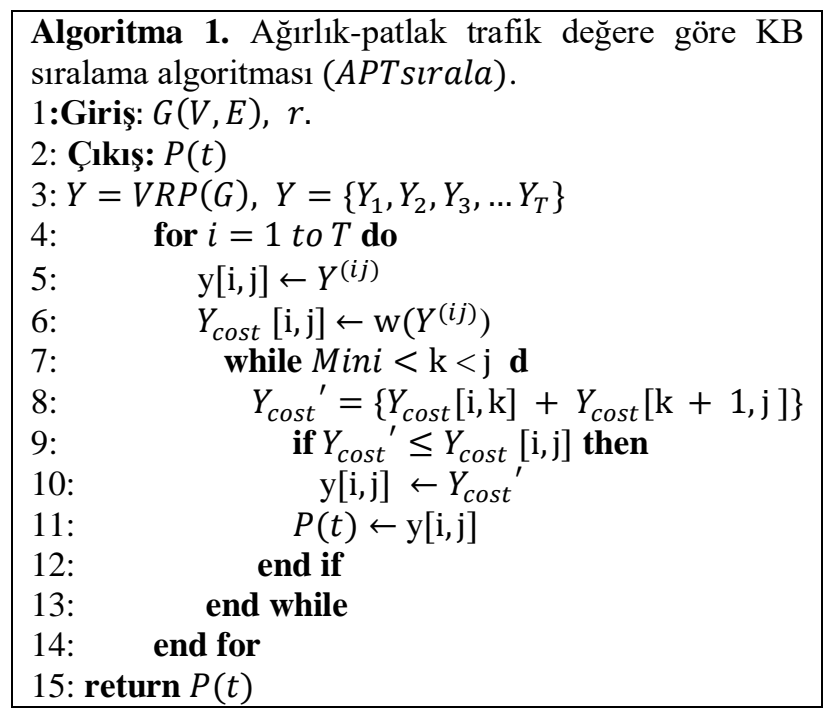

Problem Çözümü: Ağırlık-patlak trafik değere göre KB sıralama algoritması (APTsırala).

Denklem (21)'de, $z_{i m}, m$. GA grubuna ait olan $i$. KB düğümü için patlak trafiğe sahip olup olmadığını belirler.

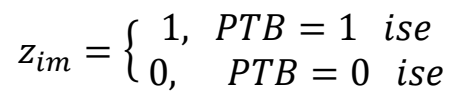

Dolasılya, $x_{e m}, y_{i m}, z_{i m}$ kullanılarak tüm $K B^{r}$ 'ler için yol sıralamaları hesaplanmak için denklem (22) tasarlanır. Burada , $\mathrm{v}_{m}$, GA düğümün adaptif belirlenmiş hızıdır. Bu ifade minimize edilerek $Y$ olarak tanımlanan birçok GA yol güzergâhları oluşur.

Minimize edilir $\max _{1 \leq \mathrm{m}=2} \sum_{\boldsymbol{e} \in E} d_{e} x_{e m} \frac{\sum_{i \in K B} r_{s e t} y_{i m *} z_{i m}}{2 * \mathrm{v}_{m}}$

Daha sonra, elde edilen $Y$ yollarını ağırlık sıralamasından da geçirmek için graftan yararlanılır. Bir graf $\mathrm{G}=(V, E)$ ile ifade edilirse ve belirli bir kaynak $(\mathrm{k})$-hedef(h) verilen $\mathrm{k}-\mathrm{h}$ ile ilişsisinde, $\mathrm{Y}=$ $\left\{\mathrm{Y}_{1}, \ldots \ldots \ldots, \mathrm{Y}_{T}\right\}$ arasında bir gezgin yol bulunur. $T$ gezgin yol sayısıdır. Bu yolun ağırlığ $($ weight, w) denklem (23)'teki gibi hesaplanır. $\mathbf{v}_{m}$ ise gezginlik hızı olarak kullanılmaktadır.

$w=w(Y)=\sum_{i=1}^{T} w_{i}\left(Y_{i}\right)+\sum_{i=1}^{T-1} c *\left(Y_{i}, Y_{i+1}\right)$ 
$c=\frac{1}{B_{\text {dec }}}$

w'si minimum olan minimum gezgin yol olarak atanır. Ağırlı̆̆ özelliği ağırlık parametresine ve yoldaki KB'lere ait patlak trafiğe göre denklem (24)'e göre belirlenir. $\mathrm{y}[\mathrm{i}, \mathrm{j}]=Y^{(i j)} \ldots . Y^{(i j)} \mathrm{j}-\mathrm{i}+1$ benzer yollar olup $Y_{\text {cost }}[\mathrm{i}, \mathrm{k}], Y_{\text {cost }}[\mathrm{k}+1, \mathrm{j}]$ iki dizinin birleştirilmesi anlamına gelir. Algoritma 1' e göre $Y=V R P(G)$ tanımlaması yapılır. Son olarak maliyeti en düşük olan $Y_{\text {cost }}{ }^{\prime}$ yol, GA düğ̈üün güzergâhı $P(t)$ olarak atanmak için kullanılır.

Varsayım: Kablosuz ağda, her küme gruplarına ait GA düğümler graftaki tüm y[i,j] güzergâhlarını ve KB dügüm koordinatlarını bilmektedir. Başlangıçta ağdaki tüm KB’ler dügümm enerjilerine göre seçilmiş bulunmaktadir.

Burada asıl amaç sadece olabildiğince en kısa yolla GA güzergâhları belirlemek değil, diğer çalışmaların aksine adaptif-efektif ve patlak trafik farkındalı bir GA gezginlik modelleri oluşturmaktır. Aslında, GA yol güzergâhı Algoritma 1'e göre sıralı şekilde belli olur.

Patlak trafik farkındalı adaptif gezginlik modeli (PTGM), Algoritma 2'de sözde kod olarak sunulmuştur.

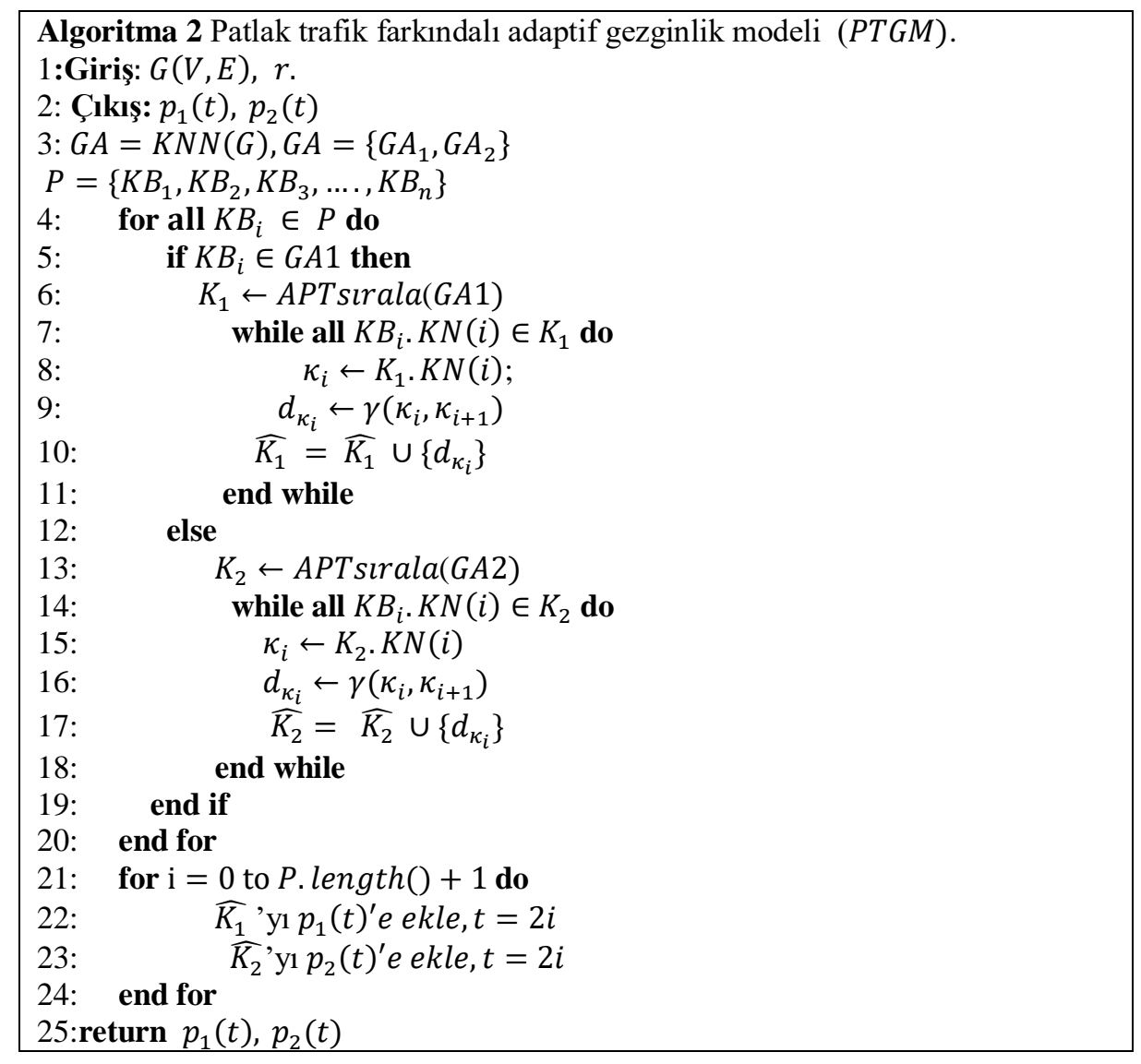

GA düğümlerin yörüngelerini belirlerken bir protokol tarafından kullanılan yolun maliyetinin, aynı ağ geçmişi için optimum gezgin yolun maliyetine (cost) olan ortalama oranı dikkate alınmıştır. Bir oturumda kullanılan yolun topoloji değişiklikleri gibi ă̆ dinamikleri nedeniyle zaman içinde değişebileceği düşünülmüştür. Küme grubu içerisinde alıc1 düğümün en k1sa yolu bulunurken optimizasyon problemlerine tipik olarak uygulanan dinamik programlama metodu kullanılmaktadir. Küme grubundaki tüm olası yollar bir $G(V, E)$ grafinda kaydedilir. Bu grafta $G A_{1}$ ve $G A_{2}$ en yakın komşuluğa göre $G A=K N N(G)$ şeklinde gruplanır. Daha sonra KB'ler kümesi $P$ 'ye dâhil olanlar hangi GA'ya bağlıysa o gruba APTsırala algoritması uygulanarak $K_{1}$ ve $K_{2}$ siralı KB kümeleri elde edilir. Bundan sonra KB'lerin konum noktalarının bulunması için $K N(i)^{\prime}$ ler öklit algoritmasıyla $\kappa_{i}$ olarak belirlenir. $d_{\kappa_{i}}$ kesişim noktalarının uzaklıkları belirlenerek bu uzaklıklar $\widehat{K_{1}}$ ve $\widehat{K_{2}}$ olarak birleştirilir. 
Son olarak bu birleştirilen uzunluklar GA'ların yol güzergâhları olarak $p_{1}(t)$ ve $p_{2}(t)$ atanır. Sonuç olarak; adaptif ve trafik farkındalı gezginlik modeli üretilmiş olur.

\section{Bulgular ve Tartışma}

Önerilen BTA-MM olarak adlandırılan şema, Ubuntu 14.04 LTS işletim sisteminde kurulu NS-2 ortamını kullanarak benzetimler yoluyla mevcut yöntemler olan DPPMSBT [17], MEACBM [12] ve EGRPM [18] yöntemleriyle karşılaştırılmıştır.

\subsection{Benzetim Kurulumu}

Bu çalışmada kullanılan benzetim parametreleri için Tablo 1'i sunuyoruz. Şekil 5'ten de görüldügü üzere NS-2 programında yazılan tüm benzetim kodları Tcl benzetim kodlarında tutulur. Terminal ekranında proje dosyasının olduğu yere ulaşıp "proje. $t c l$ " dosyası çalıştırıldığında benzetim bileşenleri C++ ve OTcl (Object Tcl, Nesne Tcl) altyapısıyla NS-2 Shell çalıştırılabilir komut satırlarına dönüşür. Bu şekilde oluşan benzetim izleme dosyası (trace file), Ağ animasyon (Network Animation, NAM) dosyaları sayesinde ağ animasyonu yapılmasına olanak sağlar. AWK kodları kullanarak izleme dosyaları (Trace File) çıktı olarak alınmıştır. AWK, ismini Alfred Aho, Peter Weinberger ve Brian Kernighan adlı yazarların soyadlarının baş harflerinden almış yorumlanabilir bir programlama dilidir. AWK programlama dilinin metin işleme, biçimlendirilmiş metin raporları üretmek, aritmetik işlem yapmak, dize işlemleri yapmak ve daha pek çok işlem gerçekleştirme özelliği vardır.

Benzetim senaryolarında ".tr" uzantılı dosyalar ve NS-2'ye kurduğumuz XGraph programı sayesinde performans analiz sonuçları elde edilmiştir. $\mathrm{Bu}$ dosyalarda oluşan analiz verileri excel formatında performans sonucu olarak sunulabilir.

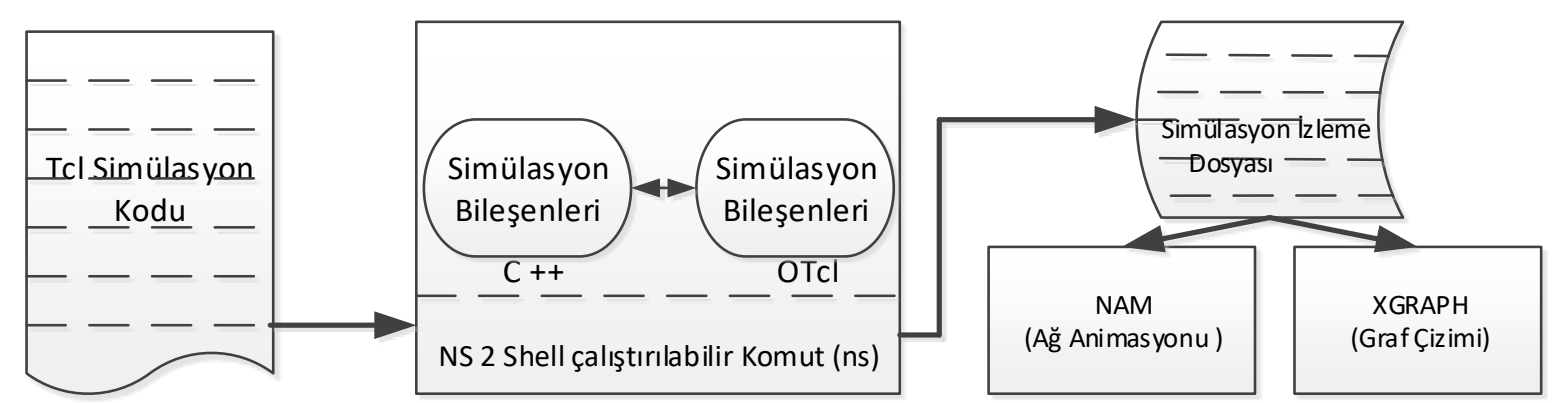

Şekil 5. NS2'de benzetim dosyaları ile ağ animasyonun ve graf çiziminin yapılması

BONNMOTION aracı kullanarak adaptif gezginlik senaryoları oluşturulmuş ve oluşturulan komut dosyalarını TCL komut dosyalarına entegre edebilmeleri için desteklenen NS-2 biçimine dönüştürülmüştür. Sabit bit oranı (Constant bit rate, CBR) ve transfer kontrol protokol (Transfer control protocol, TCP)'nin rasgele trafik bağlantıları, trafik senaryosu oluşturucu komut dosyası (cbrgen. tcl) kullanılarak GA düğümler arasında ayarlanabilir.

Kablosuz gezgin düğümler arasında CBR ve TCP trafik bağlantıları oluşturmak için kullanılabilir. $\mathrm{Bu}$ dosya önerilen yönteme göre geliştirilmiştir. Trafik bağlantısı dosyası oluşturmak için, CBR düğüm sayısını ve aralarında ayarlanacak maksimum bağlantı sayısının tanımlanması gerekir. CBR genellikle sınırlı kapasite kanallarındaki multimedya trafiğini simüle etmek veya analiz edilen diğer uygulamaların performansını etkilemek için arka plan trafiğini doldurmak için kullanılır. TCP kaynakları, ağın yüküne adapte oldukları için seçilmemektedir. Benzetimler, CBR trafik kaynaklarına sahip farklı sayıda dügümler için saniyede birden fazla paket hızında (örn. 2, 3, 4 vs.) trafik modelleri üretilmiştir. Belirli saniyelerle duraklama süreleri, minimum ve maksimum hız, belirli topoloji sınırına sahip farklı sayıda dügüum kullanan ve benzetim süresi için gezginlik modelleri oluşturulmuştur. Çalışmamızdaki benzetimlerde, örnek olarak v $=150$ paket/sn, $\partial_{\rho}=10, \partial=50$ paket ve $\mathrm{K}_{\mathrm{u}}$ Algoritma 1'den sonra belirlenen herhangi bir KB'ye ilişkili olan küme üye sayısıdır. Bu değerler verilerek patlak trafik senaryoları oluşturulmuştur. 
Tablo 1. Benzetimlerde kullanılan parametreler

\begin{tabular}{|c|c|}
\hline Parametreler & Değerler \\
\hline A ğ simülatörü & NS-2 \\
\hline Toplam düğüm sayısı $(\boldsymbol{N})$ & $100-500$ \\
\hline A & $200 \times 200 \mathrm{~m}^{2}-500 \times 500 \mathrm{~m}^{2}$ \\
\hline Normal düğüm sayısı & $N * 0.6$ \\
\hline Gelişmiş düğüm sayısı & $N * 0.3$ \\
\hline Süper düğüm sayısı & $N * 0.1$ \\
\hline Normal düğüm başlangıç enerjisi & $1 \mathrm{~J}$ \\
\hline Gelişmiş düğüm başlangıç enerjisi & $2 \mathrm{~J}$ \\
\hline Veri paket boyutu $(\boldsymbol{l})$ & 2000 bit \\
\hline İletişim aralığ $1(\boldsymbol{C R})$ & $30 \mathrm{~m}$ \\
\hline Algılayıcı düğüm dağıtımı & Tekdüze \\
\hline Baz istasyonu (BS) & $(0,0)$ \\
\hline Benzetim süresi & 2000 saniye \\
\hline$N_{\text {ack }}$ & 200 bit \\
\hline$p$ & 0.2 \\
\hline $\boldsymbol{k}$ & 2500 \\
\hline$A$ & 40 \\
\hline$t_{\text {elec }}$ & $0.3 \times 10^{-3}$ saniye \\
\hline$N_{\operatorname{cog}}$ & 4000 \\
\hline$v$ & 150 paket/sn \\
\hline$\partial_{p}$ & 10 \\
\hline$\partial$ & 50 paket \\
\hline$\propto$ & 0.01 \\
\hline$\omega$ & 0.02 \\
\hline$\varphi$ & 0.03 \\
\hline
\end{tabular}

Şekil 6'da önerilen kümeleme ve KB sıralama için yazılan Algoritma 1'in kod parçasını göstermektedir. Şekil 6'dan da görüldüğü üzere örnek olarak 3 dügü̈mün komşuluk düğümleri belirlenmiştir.

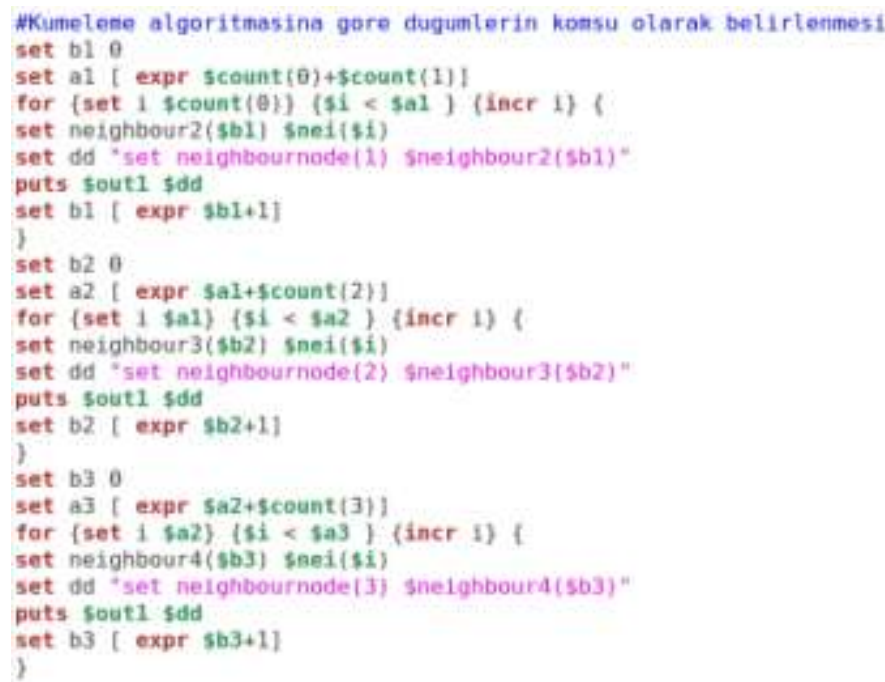

Şekil 6. Kümelemede düğümlerin komşu düğümlerinin sıralanarak KB’lerin bağlanması

Şekil 7, çalışmadaki gezgin dügümlerin yapılandırma kodlarını ve animasyon dosyalarının çalıştırılması esnasındaki örnek bir görüntüsünü vermektedir. Şekil 7'de, "proje.tcl” dosyası, "mobile.nam" dosyası ve terminal ekranı bir arada nasıl kullanıldığ aktarılmıştır ve proje dosyalarının çalışma şekli gösterilmiştir. Şekil $8,500 \times 500 \mathrm{~m}^{2}$ ağ boyutunda konuşlandırılmış 100 düğüm için önerilen kümeleme oluşumuyla heterojen ağ modelini göstermektedir. A ğda, KB'ler kırmızı boyalı düğümlerle temsil edilirken diğerleri siyah boyalı düğümlerdir. Yeşil renkli GA1 ve GA2 ise sirasıyla 1. ve 2. küme grubuna ait gezgin alıcı dügümleri temsil eder. Şekil 8'den de açıkça görülmektedir ki GA'lar 
KB'lerin konum noktalarına eriştikleri zaman verileri bu dügümlerden toplarlar. Dahası, GA1 ve GA2'nin mobil yörüngeleri birbirinden farklı oluşmaktadır. Toplam mobil yörünge uzunluğu bu iki GA'nın aldığı yol uzunluğunun toplamı şeklinde hesaplanır. Böylece düğüm trafik yoğunluğu esas alınarak ağdaki veri çarpışması olabildiğince azaltılarak enerji verimliliği iyileştirilmiş olur. Benzetimlerde KAA-1 ve KAA-2 olmak üzere 2 adet senaryo düşünülmüştür. KAA-1 ve KAA-2, sırasıyla $200 \times 200 \mathrm{~m}^{2}$ ve $500 \times 500 \mathrm{~m}^{2}$ 'lik ağ alanlarından oluşan ağ simülasyon senaryolarını belirtmektedir.

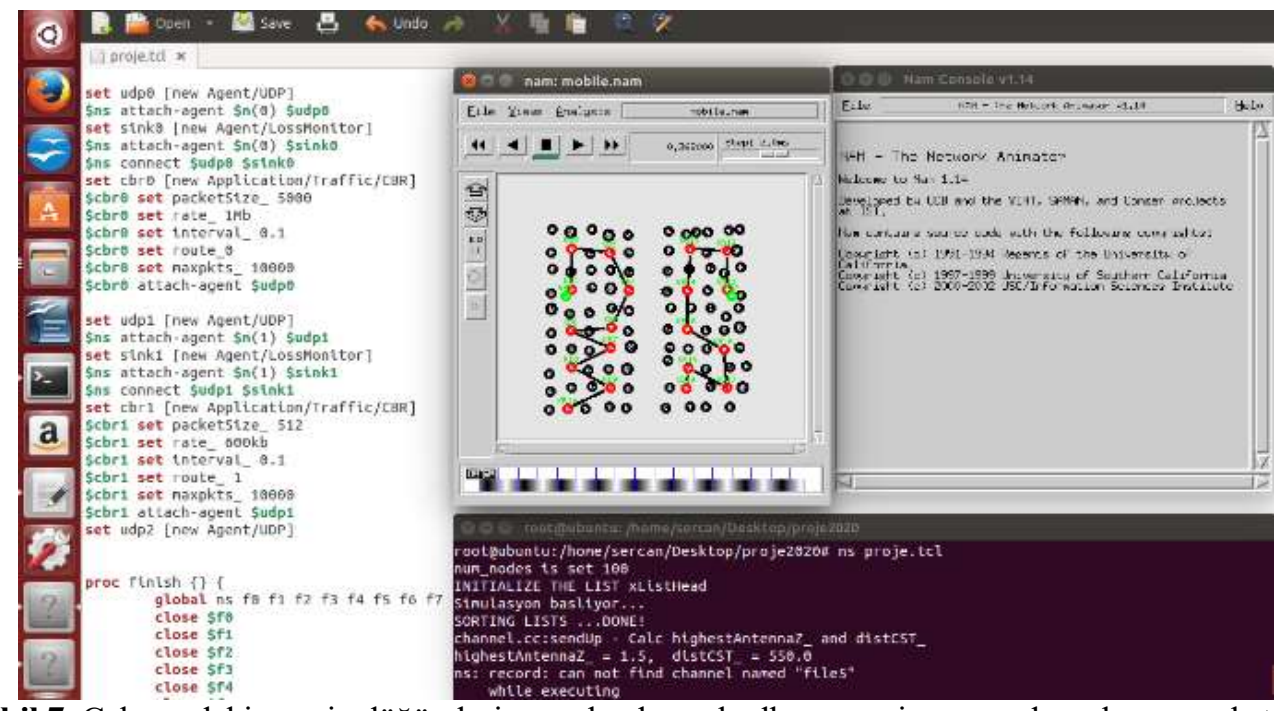

Şekil 7. Çalışmadaki gezgin düğümlerin yapılandırma kodları ve animasyon dosyalarının çalıştırılması

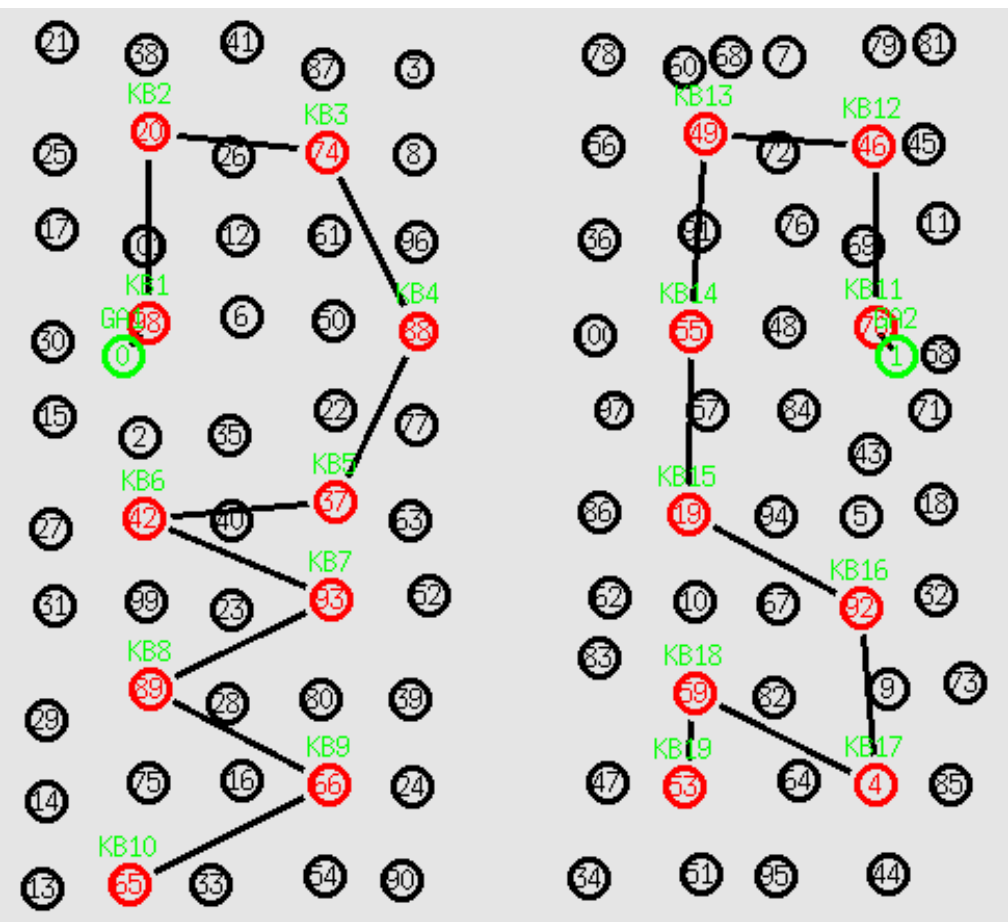

Şekil 8. Oluşturulan kümeli bir KAA topolojisi: KB’lerin seçilmesi ve GA yörüngesinin belirlenmesi

\subsection{Benzetim Sonuçlarının Değerlendirilmesi}

\subsubsection{A $\breve{g}$ Ömrünün Değerlendirilmesi}

Ağ ömrü simülasyon süresince gezgin alıcının toplam mobil tur sayısıdır $(R)$. Bu performans analizinde, ağın yoğunluğuna göre değerlendirmek için ağ alanına 100 ile 500 dügüm arasında değişen düğümler 
dağıtılmıştır. Önerilen yöntem, KAA-1 ve KAA-2 olmak üzere iki adet senaryo ile tüm algoritmalar arasında değerlendirilmiştir. Şekil 9'dan, 100 düğümlü ağda, önerilen yöntemle 14528 tur ağ ömrü başarılmasına rağmen, EGRPM, MEACBM ve DPPMSBT yöntemlerinde sirayla 12761, 11245 ve 9820 tur başarı sağlanabildiği görülmektedir. Şekil 9 ve Şekil 10'dan, ağdaki düğüm sayısı artıkça ağ ömrünün de artığı gözlenmiştir.

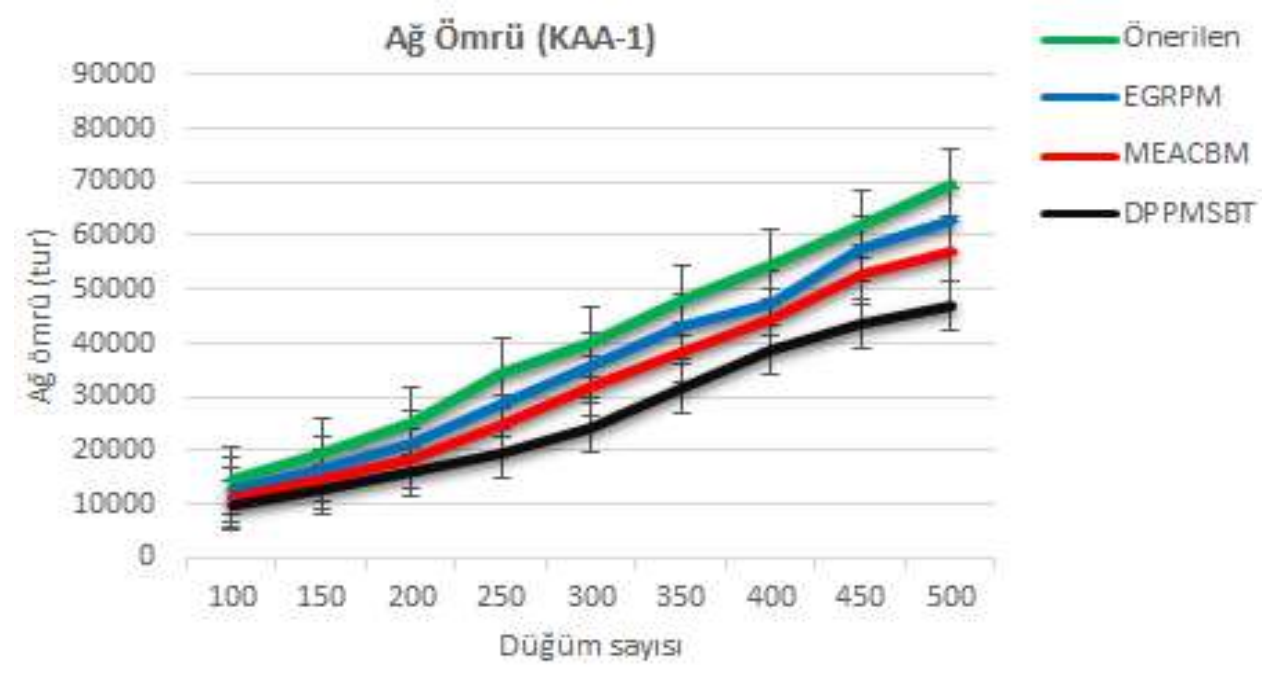

Şekil 9. Ağ ömrünün ağdaki düğüm sayısına göre performans analizi (KAA-1)

Şekil 9'dan da anlaşıldığı üzere, 500 dügümmlü ağda, önerilen yöntemle 69843 tur ağ ömrü başarılmasına rağmen, EGRPM, MEACBM ve DPPMSBT yöntemlerinde sirayla 62749, 57267 ve 46878 tur başarı sağlanmıştır.

Şekil 11'den, ağ alanı artıkça bütün algoritmalar için ağ ömrünün azaldığı gözlenmiştir. Ancak, önerilen yöntem çalıştırıldığında 500 x $500 \mathrm{~m}^{2}$ 'lik ve 500 düğümlü ağda en yüksek olarak 64924 a ğ ömrü elde edilmiştir. Görüldüğü üzere en yüksek performans önerilen metotla başarılmıştır. Bunun nedeni, önerilen yöntemlerin en iyi KB ve gezgin GA yolu keşfedebilmesidir.

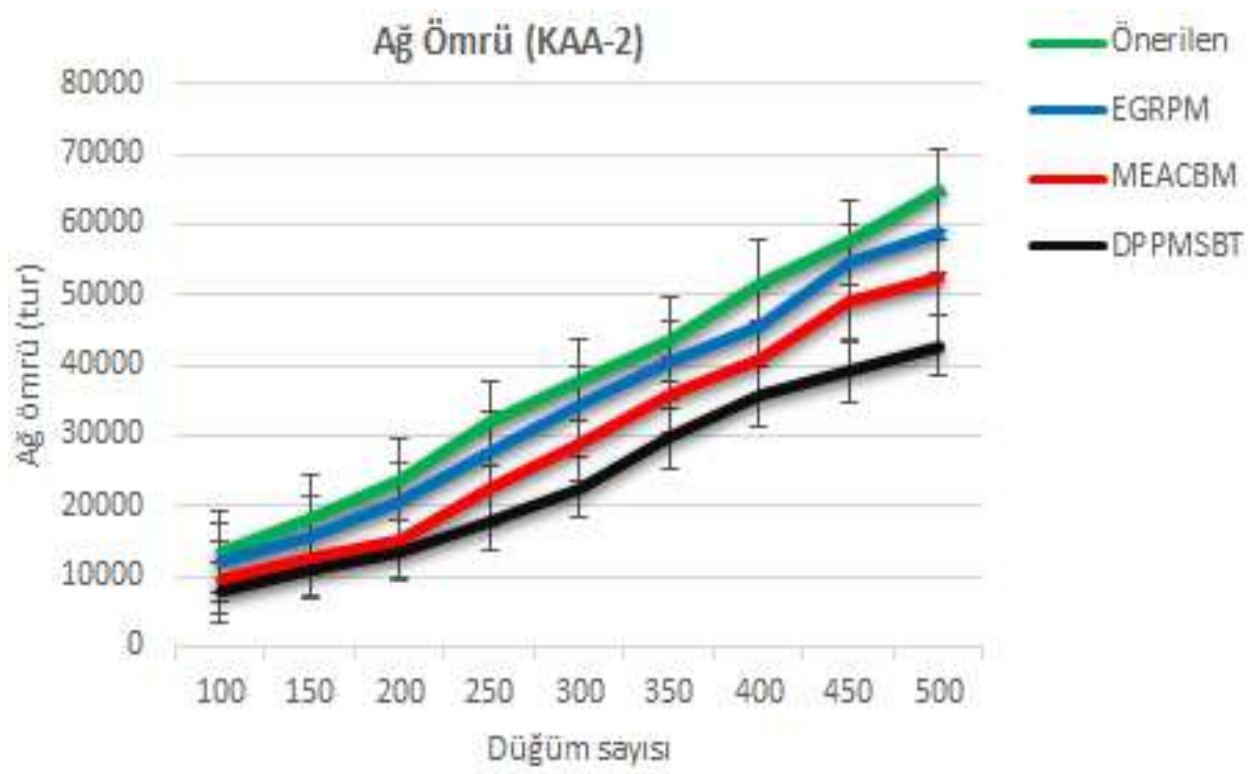

Şekil 10. Ağ ömrünün ağdaki düğüm sayısına göre performans analizi (KAA-2)

\subsubsection{Ortalama Enerji Tüketiminin Değerlendirilmesi}

Ortalama enerji tüketimini ağdaki düğümler tarafindan tüketilen ortalama enerji miktarı olarak denklem (25)'teki gibi tanımlıyoruz. Burada, $N_{e c}$ ağda tüketilen toplam enerji miktarıdır. Önerilen yöntem, KAA- 
1 ve KAA-2 olmak üzere iki adet senaryo ile tüm algoritmalar arasında değerlendirilmiştir. $\mathrm{Bu}$ performans analizinde, ağın yoğunluğuna göre değerlendirmek için ağ alanına 100 ile 500 düğüm arasında değişen düğümler dağıtılmıştır. Benzetimler için Tablo 1'deki parametreler kullanılmıştır. Şekil 11 ve 12 'de görüldügü gibi önerilen algoritma ile en düşük ortalama enerji tüketiminin sağlandığ1 görülmektedir. Örneğin Şekil 11 (KAA-1), 100 düğümlü ağda, önerilen algoritma, EGRPM, MEACBM ve DPPMSBT yöntemleri çalıştı̆̆ında sırasıyla $0.0105,0.0119,0.0135$ ve $0.0155 \mathrm{~J}$ ortalama enerji tüketimine sebep olduğunu açıkça göstermektedir. Şekil 12'den (KAA-2), büyük ölçekli ağlarda tüm algoritmalarda ortalama enerji tüketim artışının yaşandığı anlaşılmaktadır. Ancak, minimum enerji tüketimi önerilen algoritma tarafından sağlanır. Önerilen patlak trafik farkındalı yöntem ile ağda optimum ve dengeli kümeleme alt yapısı elde edilmiş ve önerilen algoritma en iyi performansı göstermiştir.

$E_{\text {ort }}=\frac{N_{e c}}{R}$

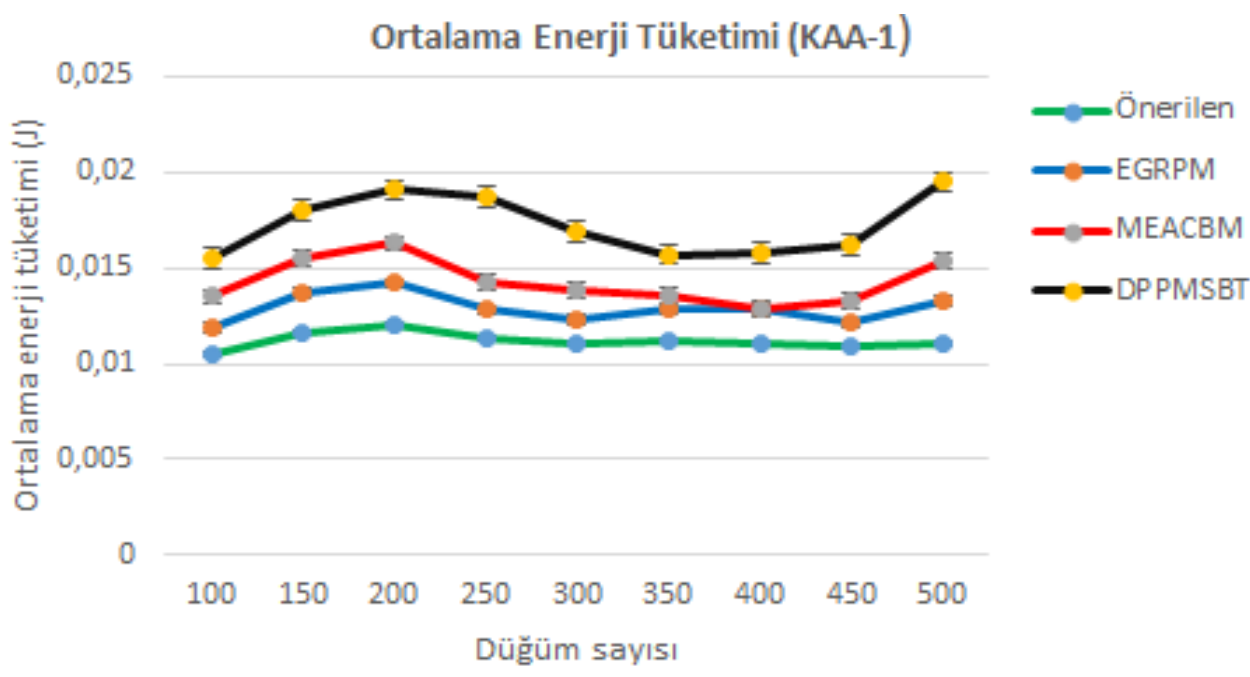

Şekil 11. Ortalama enerji tüketiminin ağdaki düğüm sayısına göre performans analizi (KAA-1)

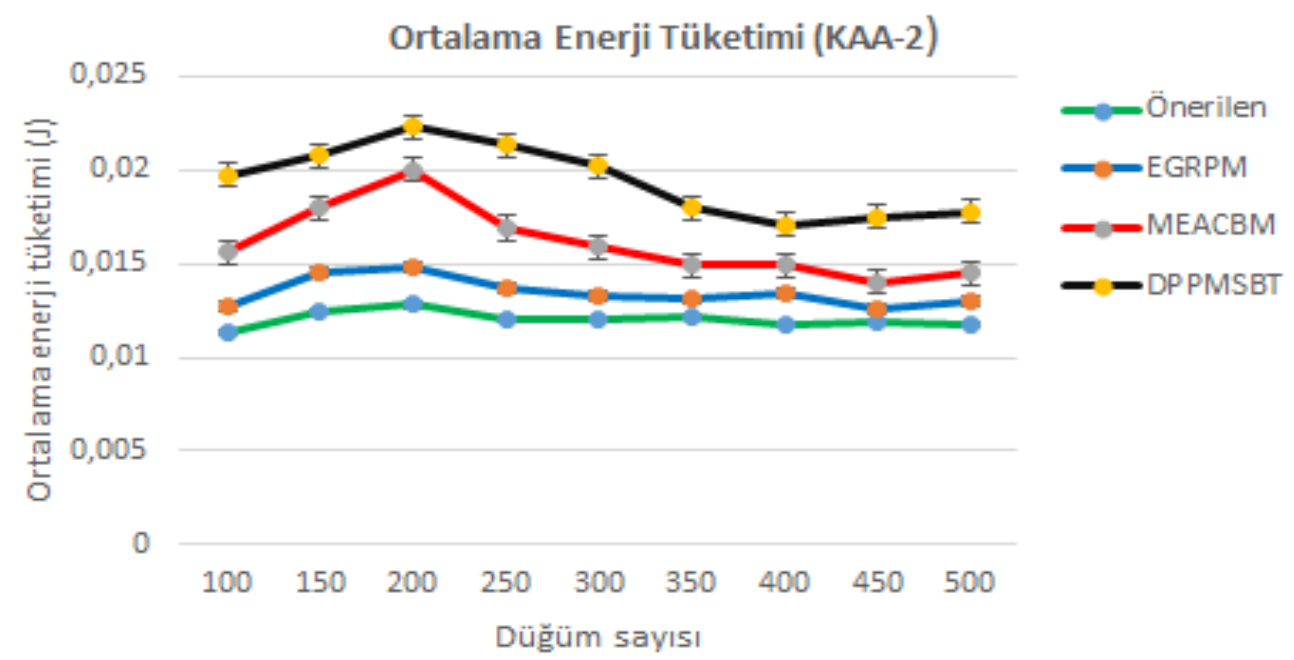

Şekil 12. Ortalama enerji tüketiminin ağdaki düğüm sayısına göre performans analizi (KAA-2)

\section{Sonuç ve Öneriler}

$\mathrm{Bu}$ çalışmada, KAA'larda enerji tüketimi, gezgin yol planlaması ve patlak veri trafiği problemlerini çözebilmek için heterojen KAA'larda yeni bir trafik kontrollü yönlendirme yöntemi önerilmiştir. Önerilen yöntemde, iki farklı yöntem önerilmiştir. Algoritma 1'de, ağırlık-patlak trafik değere göre küme baş1 sıralama algoritması (APTsırala) geliştirilmiştir. Algoritma 2'de ise, patlak trafik farkındalı adaptif gezginlik modeli (PTGM) önerilmiştir. Algoritma 2, Algoritma 1 ile birlikte çalıştırıldığında, gezgin 
alıcılar tüm KB'lerin sınırına girer girmez tek-atlamalı tutumla tüm verileri toplar dolaşarak ağdaki tüm verileri toplarlar. Önerilen protokolü var olan çalışmalarla kıyaslamak için NS-2 benzetim platformunda ağ ömrü ve ortalama enerji tüketimi kriterlerince performans analizleri yapılmıştır. Benzetim sonuçları, önerilen protokolün diğer çalışmalardan üstün sonuçlar verdiğini göstermiştir.

Ancak, bu çalışmada gezgin alıcı düğümlerin hızları tam olarak belirlenememiştir. Ayrıca, önerilen algoritmaların patlak trafik karar değerleri optimize edilmemiştir. $\mathrm{Bu}$ nedenle gelecek çalışmalarımızda, bu çalışmadaki algoritmaları adaptif gezgin hız algoritması ve patlak trafik karar mekanizmalarıyla birleştirilerek daha verimli yöntemler önerilmesi planlanmaktadır.

\section{Teșekkür}

$\mathrm{Bu}$ çalışma Türkiye Bilimsel ve Teknolojik Araştırma Kurumu (TUBITAK) tarafindan 120E379 numaralı proje ile desteklenmiştir.

\section{Yazarların Katkısı}

Yazarlar makaleye eşit oranda katkı sağlamıştır.

\section{Çıkar Çatışması Beyanı}

Yazarlar arasında herhangi bir çıkar çatışması bulunmamaktadır.

\section{Araştırma ve Yayın Etiği Beyanı}

Yapılan çalışmada araştırma ve yayın etiğine uyulmuştur.

\section{Kaynaklar}

[1] Singh J., Kaur R., Singh D. 2020. A survey and taxonomy on energy management schemes in wireless sensor networks. Journal of Systems Architecture, 111: https://doi.org/10.1016/j.sysarc.2020.101782.

[2] Mehrabi A., Kim K. 2015. Maximizing data collection throughput on a path in energy harvesting sensor networks using a mobile sink. IEEE Transactions on Mobile Computing, 15 (3): 690-704.

[3] Vancin S., Erdem E. 2017. Implementation of the vehicle recognition systems using wireless magnetic sensors. Sadhana Springer, Indian Academy of Sciences, 42 (6): 841-854.

[4] Khan R.A., Pathan A.S.K. 2018. The state-of-the-art wireless body area sensor networks: A survey. International Journal of Distributed Sensor Networks, 14 (4): 1-23.

[5] Shi J., Wei X., Zhu W. 2016. An efficient algorithm for energy management in wireless sensor networks via employing multiple mobile sinks. International Journal of Distributed Sensor Networks, 12 (1): 1-9.

[6] Kim B.S., Park H., Kim K.H., Godfrey D., Kim K.I. 2017. A survey on real-time communications in wireless sensor networks. Wireless Communications and Mobile Computing, 2017, 1-13.

[7] Thomson C., Wadhaj I., Tan Z., Al-Dubai A. 2021. Towards an energy balancing solution for wireless sensor network with mobile sink node. Computer Communications, 170: 50-64.

[8] Yarinezhad R., Hashemi S.N. 2019. Solving the load balanced clustering and routing problems in WSNs with an fpt-Approximation algorithm and a grid structure. Pervasive and Mobile Computing, 58: 101033.

[9] Thomas S., Mathew T. 2018. Intelligent Path Discovery for a Mobile Sink in Wireless Sensor Network. Procedia Computer Science, 143: 749-756.

[10] Mohemed R.E., Saleh A.I., Abdelrazzak M., Smara A.S. 2017. Energy-efficient routing protocols for solving energy hole problem in wireless sensor networks. Computer Networks, 114: 51-66.

[11] Sabor N., Sasaki S., Abo-Zahhad M., Ahmed S.M. 2017. A comprehensive survey on hierarchicalbased routing protocols for mobile wireless sensor networks: review, taxonomy, and future directions. Wireless Communications and Mobile Computing, 2017: 1-23. 
[12] Toor A.S., Jain A.K. 2019. Energy Aware Cluster Based Multi-hop Energy Efficient Routing Protocol using Multiple Mobile Nodes (MEACBM) in Wireless Sensor Networks. International Journal of Electronics and Communications (AEÜ), 102: 42-53.

[13] Darabkh K.A., Odetallah S.M., Alqudah Z., Khalifeh A.F., Shurman M.M. 2019. Energy-Aware and Density-Based Clustering and Relaying Protocol (EA-DB-CRP) for gathering data in wireless sensor networks. Applied Soft Computing, 80: 154-166.

[14] Parashar V., Mishra B., Tomar G.S. 2020. Energy Aware Communication in Wireless Sensor Network: A Survey. Materialstoday: Proceedings, 29 (2): 512-523.

[15] Daas M.S., Chikhi S., Bourenname El-Bay. 2021. A dynamic multi-sink routing protocol for static and mobile self-organizing wireless networks: A routing protocol for Internet of Things. Ad Hoc Networks, 117: https://doi.org/10.1016/j.adhoc.2021.102495.

[16] Shahraki A., Taherkordi A., Haugen Q., Eliassen F. 2020. Clustering objectives in wireless sensor networks: A survey and research direction analysis. Computer Networks, 180: https://doi.org/10.1016/j.comnet.2020.107376.

[17] Zhang L., Wan C. 2019. Dynamic Path Planning Design for Mobile Sink with Burst Traffic in a Region of WSN. Wireless Communications and Mobile Computing, 2019, Article ID 2435712: 18.

[18] Naghibi M., Barati H. 2020. EGRPM: Energy efficient geographic routing protocol based on mobile sink in wireless sensor networks. Sustainable Computing: Informatics and Systems, 25 (2020): 1-10.

[19] Yalçın S., Erdem E. 2019. Bacteria Interactive Cost and Balanced-Compromised Approach to Clustering and Transmission Boundary-Range Cognitive Routing in Mobile Heterogeneous Wireless Sensor Networks. Sensors, 19: 867.

[20] Agamy A.F., Mohammed A.M. 2017. Performance Modeling of WSN with Bursty Delivery Mode. Computer Science of Cornell University, 1-12.

[21] Christofides N., Mingozzi A., Toth P. 1979. The Vehicle Routing Problem. Wiley, Chichester, UK, 315-338. 